\title{
Medium pH and Leaf Nutrient Concentration Influence Rust Pustule Diameter on Leaves of Dry Beans
}

\author{
Haytham Z. Zaiter ${ }^{1}$, Dermot P. Coyne ${ }^{2}$, Ralph B. Clark ${ }^{3}$, and \\ James R. Steadman ${ }^{4}$ \\ University of Nebraska, Lincoln, NE 68583-0724 \\ Additional index words. Phaseolus vulgaris, Uromyces appendiculatus var. \\ appendiculatus, genotypic variation, interactions for rust reaction, mineral elements
}

\begin{abstract}
Nine bean cultivars/lines (Phaseolus vulgaris L.) were grown in three soils/ rooting media at $\mathrm{pH}$ values of $7.9,6.5$, and 5.8 in greenhouse, growth chamber, and field experiments to evaluate the leaf reaction of the plants to a Nebraska bean rust [Uromyces appendiculatus (Pers.) Unger var. appendiculatus] isolate US85-NP-10-1. Significant differences were observed for rust pustule diameter between cultivars/lines grown in the three growth media. Plants grown in the medium at $\mathbf{p H} 5.8$ showed significantly larger rust pustule diameters than those of plants grown at $\mathbf{p H} 6.5$ or 7.9. A significant interaction occurred between growth medium and cultivars/lines for the rust reaction. Concentrations of $\mathrm{Cl}$ and $\mathrm{Mn}$ in leaves were positively correlated with rust pustule diameter. In contrast, concentration of $\mathrm{K}$ in leaves was negatively correlated with rust pustule diameter. Plant breeders attempting to improve beans for rust resistance must consider the growth medium $\mathrm{pH}$ in evaluating intensity and severity of rust symptoms on leaves.
\end{abstract}

Even though plant disease response to host plant nutrition in horticultural and field crops has been reported (Forsyth, 1957; Gallegly and Walter, 1949; Platero and Tejerina, 1976; Walker, 1946), we found no reports on the effects of host plant nutrition, growth medium $\mathrm{pH}$, and rust interaction in dry bean. Very little information is available about the effects of host nutrition on rust development, although other aspects of the disease have been studied thoroughly (Gersbeck and Schonbeck, 1988). The objectives in this research were to a) evaluate the effects of growth medium $\mathrm{pH}$ on rust development, and b) de-

Received for publication 1 Aug. 1990. Published as Paper no. 9293, Journal Series, Nebraska Agricultural Experiment Station. Research was conducted under Title XII Bean/Cowpea CRSP ProjectUniv. of Nebraska, Univ. of Puerto Rico and Dominican Republic under AID Contract no. DAN1310-G-SS-6008-00 and also under Project nos. 20-036 and 20-042. Mention of trade name, proprietary product, or vendor does not constitute an endorsement or warranty by the Univ. of Nebraska or the U.S. Dept. of Agriculture, nor does it imply its approval to the exclusion of other products or vendors that also may be suitable. The cost of publishing this paper was defrayed in part by the payment of page charges. Under postal regulations, this paper therefore must be hereby marked advertisement solely to indicate this fact.

${ }^{1}$ Research Associate, Dept. of Horticulture, Univ. of Nebraska, Lincoln, NE 68583-0724. Presently ssistant Professor, Crop Production and Protection Dept., American Univ. of Beirut, Republic of Lebanon.

George Holmes Professor, Dept. of Horticulture, Univ. of Nebraska, Lincoln, NE 68583-0724. ${ }^{3}$ Research Plant Physiologist, ARS/U. S. Dept. of Agriculture, Dept. of Agronomy, Univ. of $\mathrm{Ne}$ braska, Lincoln, NE 68583-0817.

${ }^{4}$ Professor, Dept. of Plant Pathology, Univ. of Nebraska, Lincoln, NE 68583-0722. termine the relationship between the rust reaction of the plants and the nutrient concentrations of the leaf tissue.

Eight cultivars/lines of dry beans with known differences in reaction to one $\mathrm{Ne}$ braska isolate (US85-NP-10-1) of the bean rust pathogen were grown in three media in the greenhouse (Expt. I) and in the growth chamber (Expts. II and III). Medium 1 was Tripp sandy clay loam soil (coarse-silty, mixed, mesic Aridic Haplustolls) from the North Platte Research and Extension Center, Univ. of Nebraska, North Platte, with $\mathrm{pH}$ $7.9,1.1 \%$ organic matter, 8.9 ppm P, 291 ppm K, 2.7 ppm NO, 0.5 ppm NH $\mathrm{N}_{4}, 10.4$ cmol Ca, $3.5 \mathrm{cmol} \mathrm{Mg}, 0.9 \mathrm{cmol} \mathrm{K}$, and 0.8 cmol Na/kg of soil. Medium 2 was Sharpsburg silty clay loam (fine, montmorillonitic, mesic Typic Arguidolls) from the Dept. of Horticulture experimental garden, Univ. of Nebraska, Lincoln, with $\mathrm{pH} 6.5,2.9 \%$ organic matter, 12.2 ppm P, 269 ppm K, 1.9 ppm $\mathrm{NO}_{3}, 0.6 \mathrm{ppm} \mathrm{NH}_{4}, 15.8 \mathrm{cmol} \mathrm{Ca}, 5.5$ $\mathrm{cmol} \mathrm{Mg}, 0.9 \mathrm{cmol} \mathrm{K}$, and $0.6 \mathrm{cmol} \mathrm{Na} / \mathrm{kg}$ of soil. Medium 3 was a potting mixture consisting of equal volumes of sand, soil (Sharpsburg silty clay loam), vermiculite, and peat moss, with $\mathrm{pH} 5.8,2.7 \%$ organic matter, $5.8 \mathrm{ppm} \mathrm{P}, 157 \mathrm{ppm} \mathrm{K}, 0.5 \mathrm{ppm} \mathrm{NO}$, $0.5 \mathrm{ppm} \mathrm{NH}_{4}, 5.3 \mathrm{cmol} \mathrm{Ca}, 2.8 \mathrm{cmol} \mathrm{Mg}$, $0.4 \mathrm{cmol} \mathrm{K}$, and $0.5 \mathrm{cmol} \mathrm{Na} / \mathrm{kg}$ of soil.

A randomized complete-block design with a $3 \times 8$ factorial arrangement of growing media and cultivars/lines with four replications for Expts. I, II, and III was used. The abaxial surfaces of fully unfolded primary leaves of bean seedlings of the same age were inoculated with a water suspension of urediniospores $10^{5}$ spores $/ \mathrm{ml} 7$ to 12 days after seeding, by use of a modified crown sprayer (Fisher Scientific, Pittsburgh, Pa.). Leaves were sprayed, without wounding, until com- pletely wet. After inoculation, plants were held in high humidity by covering them with clear plastic for $18 \mathrm{~h}$ (overnight). Rust pustule diameter in micrometers was measured by use of $6 \times$ edscorp pocket comparator (Edmund Scientific, Barrington, N.J.) 14 days after inoculation.

Plants were grown in 15 -cm (1.5-liter) plastic pots (two plants per pot) using the three growing media in all experiments. The air was $\approx 25 \mathrm{C}$ (14-h day) and 22C (10-h night) in Expt. I and 27C (14-h day) and 20C (10$h$ night) in Expts. II and III. In the growth chamber experiments, the photosynthetic photon flux was $340 \mu \mathrm{mol} \cdot \mathrm{s}^{-1} \cdot \mathrm{m}^{-2}$ at plant height (110 $\mathrm{cm}$ below the light source). Lamps used to provide light were high-pressure sodium (General Electric, Lucalux, LU 4008) and metal halide (General Electric, Multivapor, MV 400).

The eight cultivars/lines used were: Great Northern (GN) Belneb \#1 and GN WM185-43 (race-specific resistance to rust); 'PC50 ' and 'Jamaica Red' (race-specific and racenonspecific resistance to rust); Pinto 'UI-114' and 'US-3' (highly susceptible to rust); and GN 'Harris' and GN 'Tara' (susceptible to rust).

Nine cultivars/lines of dry beans were grown in the field (Expts. IV and V) in specially designed wooden boxes $(107 \times 32 \times$ $30 \mathrm{~cm}$ ) in the media described. In addition to the eight lines used in the growth chamber studies, PI 165078, a line susceptible to $\mathrm{Fe}$ deficiency chlorosis (Zaiter et al., 1986), was included. A split-plot arrangement of treatments with soil medium as whole-plot and cultivars/lines as subplots was used with five replications in Expt. IV and four replications in Expt. V.

Rust pustule diameter in micrometers was recorded 14 days after inoculation, as described. The abaxial surfaces of fully unfolded first trifoliates of bean seedlings of the same age (14 to 16 days after seeding) were inoculated. Seeds sown in potting mix medium germinated 2 days earlier than in the Tripp or Sharpsburg soils.

Entire leaves were collected from plants at the early bloom stage in Expt. V for determination of nutrients. The trifoliate or single leaf from the top of each plant was sampled, dried at $60 \mathrm{C}$ for $48 \mathrm{~h}$, weighed, ground to pass a $0.5-\mathrm{cm}$ screen, and analyzed for $\mathrm{Mg}, \mathrm{Al}, \mathrm{Si}, \mathrm{P}, \mathrm{Cl}, \mathrm{K}, \mathrm{Ca}, \mathrm{Mn}, \mathrm{Fe}$, $\mathrm{Cu}$, and $\mathrm{Zn}$ by energy dispersive $\mathrm{X}$-ray fluorescence (Knudsen et al., 1981).

A separate analysis of variance (ANOVA) was conducted for each of the five experiments. Appropriate $\mathrm{LSD}_{0.05}$ values were calculated to make specific treatment comparisons in Expts. IV and V as described by Steel and Torrie (1960) (Table 1). Cultivars and breeding lines that expressed an immune reaction (rating $=0$ ) (Belneb \#1, 'PC-50', and WM1-85-42) were excluded from the ANOVA because the data were discrete.

Dry bean cultivars/lines differed markedly in all experiments in susceptibility to rust in response to soil medium $\mathrm{pH}$ (Table 1). Several cultivars/lines grown at pH 5.8 (potting 
Table 1. Mean leaf rust pustule diameter $(\mu \mathrm{m})^{z}$ on greenhouse- (Expt. I), growth chamber- (Expts. II and III), and field- (Expts. IV and V) grown dry bean cultivars/lines (inoculated with rust isolate US 85-NP-10-1) in three growing media.

\begin{tabular}{|c|c|c|c|c|c|c|c|c|c|c|c|c|c|c|c|}
\hline \multirow[b]{3}{*}{ Cultivar/line ${ }^{y}$} & \multicolumn{15}{|c|}{ Mean leaf rust pustule diameter $(\mu \mathrm{m})$} \\
\hline & \multicolumn{5}{|c|}{ Tripp soil (pH 7.9) } & \multicolumn{5}{|c|}{ Sharpsburg soil (pH 6.5) } & \multicolumn{5}{|c|}{ Potting mix (pH 5.8) } \\
\hline & I & II & III & IV & $\mathrm{V}$ & I & II & III & IV & V & I & II & III & IV & V \\
\hline GN Belneb \#1 (U/N) & 0 & 0 & 0 & 0. & 117 & 0 & 0 & 0 & 0 & 34 & 0 & 0 & 0 & 0 & 0 \\
\hline GN Harris $(N)$ & 575 & 400 & 450 & 780 & 625 & 600 & 650 & 600 & 640 & 625 & 900 & 700 & 550 & 840 & 825 \\
\hline Jamaica Red (J) & 300 & 300 & 350 & 140 & 100 & 350 & 400 & 425 & 420 & 475 & 450 & 400 & 350 & 260 & 550 \\
\hline $\mathrm{PC}-50$ (DR) & 0 & 0 & 75 & 260 & 158 & 400 & 400 & 450 & 220 & 450 & 650 & 400 & 350 & 320 & 425 \\
\hline GN Tara $(\mathrm{N})$ & 300 & 350 & 300 & 580 & 500 & 575 & 500 & 525 & 440 & 350 & 550 & 400 & 575 & 740 & 775 \\
\hline Pinto UI 114 (I) & 775 & 575 & 450 & 600 & 650 & 850 & 700 & 600 & 680 & 625 & 925 & 725 & 800 & 860 & 775 \\
\hline US-3 (U) & 750 & 400 & 550 & 640 & 500 & 750 & 400 & 600 & 660 & 750 & 950 & 625 & 800 & 840 & 925 \\
\hline GN WM1-85-43 (N) & 0 & 0 & 0 & 240 & 125 & 300 & 300 & 225 & 140 & 325 & 0 & 150 & 300 & 90 & 360 \\
\hline Pl $165078(T)$ & -.- & --- & --- & 764 & 775 & $\cdot--$ & -- & $\ldots$ & 680 & 675 & -.- & ..- &.- & 780 & 850 \\
\hline \multicolumn{16}{|l|}{ Pearson correlations between } \\
\hline Expts. II \& III and IV and V & \multicolumn{3}{|c|}{$+0.83^{* *}$} & \multicolumn{2}{|c|}{$+0.85^{* *}$} & \multicolumn{3}{|c|}{$+0.57^{* *}$} & \multicolumn{2}{|c|}{$+0.61^{* *}$} & \multicolumn{3}{|c|}{$+0.75^{* *}$} & \multicolumn{2}{|c|}{$+0.79 * *$} \\
\hline
\end{tabular}

${ }^{2}$ Rust reactions: immune $=0$, resistant $=$ pustule size $\leq 300 \mu \mathrm{m}$, susceptible $=$ pustule size $>300 \mu \mathrm{m}$ (Stavely and Pastor-Corrales, 1989).

Yorigin: U/N = USDA/Nebraska; $J$ = Jamaica; $D R=$ Dominican Republic; $I=$ Idaho; $\mathrm{T}=$ Turkey.

**Significant at $P=0.01$. $L S D_{0.05}$ value to compare means for different factorial treatments $=59$ for Expt. I; LSD $_{0.05}$ value to compare means for different factorial treatments $=76$ for Expt. II and 98 for Expt. III; $L_{S D_{0.05}}$ value to compare means for the same soil type for different cultivars/lines $=157$ for Expt. IV and $=156$ for Expt. V. LSD $_{0.05}$ value to compare means of an entry between different soil types $=166$ for Expt. IV and 156 for Expt. V.

Table 2. Mineral element concentrations (MEC) in leaves of nine dry bean cultivars/lines grown in three media (Expt. V) and correlations between MEC and rust pustule size of susceptible (S) cultivars/lines.

\begin{tabular}{|c|c|c|c|c|c|c|c|c|c|c|c|c|}
\hline \multirow[b]{2}{*}{$\begin{array}{l}\text { Ions/pH/ } \\
\text { media }^{\mathrm{z}}\end{array}$} & \multicolumn{9}{|c|}{ Cultivars/lines } & \multirow[b]{2}{*}{$\mathrm{LSD}_{0.0 .5}{ }^{\mathrm{y}}$} & \multirow[b]{2}{*}{$\operatorname{LSD}_{0.05}{ }^{x}$} & \multirow[b]{2}{*}{$r$} \\
\hline & $\begin{array}{c}\text { GN } \\
\text { Bclneb \#1 }\end{array}$ & $\begin{array}{c}\mathrm{GN} \\
\text { Harris(S) }\end{array}$ & Jamaica Red & PC-50 & $\begin{array}{c}\mathrm{PI} \\
165078(\mathrm{~S}) \\
\end{array}$ & $\begin{array}{c}\text { GN } \\
\operatorname{Tara}(S)\end{array}$ & $\begin{array}{c}\text { Pinto } \\
\text { UI 114(S) }\end{array}$ & US-3(S) & $\begin{array}{c}\text { GN } \\
\text { WM1-85-43 }\end{array}$ & & & \\
\hline \multicolumn{13}{|c|}{$g \cdot \mathrm{kg}^{-1}$} \\
\hline L (PM) & 14.8 & 15.4 & 16.5 & 17.9 & 16.8 & 14.0 & 1.70 & 14.6 & 12.5 & \multirow{3}{*}{0.38} & \multirow{3}{*}{0.43} & +0.52 \\
\hline$I(S)$ & 2.3 & 2.9 & 4.5 & 6.4 & 3.4 & 3.2 & 0.41 & 2.0 & 3.0 & & & \\
\hline $\mathrm{H}(\mathrm{C})$ & 2.2 & 2.6 & 2.5 & 2.4 & 4.1 & 2.7 & 0.25 & 4.2 & 2.5 & & & $(P=0.0001)$ \\
\hline \multicolumn{13}{|l|}{$\mathrm{K}$} \\
\hline $\mathrm{L}(\mathrm{PM})$ & 21.1 & 22.3 & 24.5 & 19.5 & 25.9 & 23.0 & 25.3 & 22.9 & 23.4 & \multirow[t]{3}{*}{0.59} & \multirow[t]{3}{*}{0.68} & -0.43 \\
\hline $\mathrm{I}(\mathrm{S})$ & 31.2 & 36.2 & 40.8 & 34.6 & 32.2 & 34.5 & 35.1 & 33.7 & 32.6 & & & \\
\hline $\mathrm{H}(\mathrm{C})$ & 41.2 & 46.7 & 44.8 & 37.3 & 40.7 & 43.3 & 40.9 & 37.4 & 42.9 & & & $(P=0.0004)$ \\
\hline \multicolumn{13}{|c|}{$m g \cdot k g^{-1}$} \\
\hline MN & & & & & & & & & & \multirow{4}{*}{37.0} & & \\
\hline $\mathrm{L}(\mathrm{PM})$ & 250 & 220 & 224 & 332 & 227 & 213 & 233 & 194 & 214 & & \multirow[t]{3}{*}{49.3} & +0.44 \\
\hline I $(S)$ & 71 & 71 & 58 & 80 & 60 & 71 & 58 & 61 & 69 & & & \\
\hline $\mathrm{H}(\mathrm{C})$ & 78 & 79 & 78 & 96 & 51 & 74 & 63 & 116 & 67 & & & $(P=0.0005)$ \\
\hline
\end{tabular}

${ }^{2} \mathrm{~L}=$ low pH (5.8, PM = Potting mix); $\mathrm{I}=$ intermediate $\mathrm{pH}(6.5, \mathrm{~S}=$ Sharpsburg soil $) ; \mathrm{H}=$ High $\mathrm{pH}(7.8, \mathrm{C}=$ Tripp soil $)$.

${ }^{\mathrm{LSSD}_{0.05}}$ values to compare means for the same soil type from different cultivars/lines.

${ }^{x} L_{S D_{0.01}}$ values to compare means of an entry between different soil types.

mix) showed significantly larger rust pustule diameters than plants grown on the soils at $\mathrm{pH} 6.5$ or 7.9 . The highest mean pustule diameter on leaves was $950 \mu \mathrm{m}$ on 'US-3' plants grown on the low $\mathrm{pH}$ medium. GN Belneb \#1 (immune except in Expt. V on high and intermediate $\mathrm{pH}$ medium where pustule diameter was $<300 \mu \mathrm{m})$ was the most resistant entry and 'US-3' (pustule diameter means ranged from 400 to $950 \mu \mathrm{m}$ over all experiments) was the most susceptible entry over all experiments. Growing media $\times$ cultivars/lines interactions were detected $(\mathrm{F}$ value significant at $P<0.01)$. GN 'Harris', 'Jamaica Red', 'PC-50', GN 'Tara', and Pinto 'UI-114' were more susceptible (larger rust pustule diameter) when grown in the low $\mathrm{pH}$ medium than in the high $\mathrm{pH}$ medium, but no differences in pustule diameter were noted for PI 165078 on these two media. 'Jamaica Red' and 'PC-50', either produced an immune reaction (rating $=0$ ) or small pustules (flecking with no sporulation in pustule $\leq 300$ $\mu \mathrm{m})$ when grown on the high $\mathrm{pH}$ medium while sporulating pustules $>300 \mu \mathrm{m}$ (except in two instances) were produced in all experiments on the other two media. WM1-8543 showed an immune reaction (rating $=0$ ) in three out of five experiments on the high $\mathrm{pH}$ medium but in only one out of five experiments in the low $\mathrm{pH}$ medium. Pustule diameters $\leq 300 \mu \mathrm{m}$ occurred on leaves of WM1-85-43 in all other experiments on all media except in the case of Expt. $\mathrm{V}$ at $\mathrm{pH}$ 5.8 and 6.5 (> $300 \mu \mathrm{m})$. Moderately high positive correlations were noted between the pustule diameter on plants grown in the two growth chamber experiments (II and III) and in the two field experiments (IV and V), indicating good agreement of the data over experiments (Table 1).

Higher concentrations of $\mathrm{Cl}$ and $\mathrm{Mn}$ were noted in leaves of plants grown at $\mathrm{pH} 5.8$ than in plants grown at 7.9 or 6.5 (Table 2). In contrast, $\mathrm{K}$ concentration in leaves on plants grown in the low $\mathrm{pH}$ medium was about half that found in plants grown at high or intermediate $\mathrm{pH}$. Concentrations of the above nutrients were usually similar in resistant and susceptible cultivars/lines (Table 2). Con- centrations of $\mathrm{Cl}$ and $\mathrm{Mn}$ in leaves were positively correlated with rust pustule diameter. In contrast, concentration of $\mathrm{K}$ in leaves was negatively correlated with rust pustule diameter (Table 2). Concentrations of $\mathrm{Mg}, \mathrm{Al}$, $\mathrm{Si}, \mathrm{P}, \mathrm{Ca}, \mathrm{Fe}, \mathrm{Zn}$, and $\mathrm{Cu}$ in leaves were not correlated with pustule diameter (correlations not shown).

The degree of rust infection on dry beans was influenced by $\mathrm{pH}$ and genotype. Because of the interactions of rust development on cuhivars/lines grown on different growth media, plant breeders and plant pathologists now need to take this into consideration in evaluating and reporting on the degree of resistance and susceptibility of bean germplasm. Differences in $\mathrm{pH}$ of media may be primarily involved, but this was not proved in these experiments since the media also varied in other properties. Further experiments need to be conducted under controlled $\mathrm{pH}$, nutrient, and environmental conditions to determine the influence of $\mathrm{pH}$, each nutrient, and nutrient interactions on rust development in beans. 


\section{Literature Cited}

Forsyth, F.R. 1957. Effect of ions of certain metals on the development of stem rust in the wheat plant. Nature (London) 179:217-218.

Gallegly, M.E., Jr. and J.C. Walter. 1949. Plant nutrition in relation to disease development. V. Bacterial wilt of tomato. Amer. J. Bot. 36:613623.

Gersbeck, B. and F. Schonbeck. 1988. Sporulation and infectivity of Uromyces phaseoli in relation to pustule density and environmental conditions. Z. Pflanzenkrankheiten und Pflan- zenschutz 95(5):518-525.

Knudsen, D., R.B. Clark, J.L. Denning, and P.A. Pier. 1981. Plant analysis of trace elements by x-ray. J. Plant Nutr. 3:61-75.

Platero, M. and G. Tejerina. 1976. Calcium nutrition in Phaseolus vulgaris in relation to its resistance to Erwinia carotavora. Phytopath. Z. 85:314-319.

Stavely, J.R. and M.A. Pastor-Corrales. 1989. Rust, p. 159-194. In: H.F. Schwartz and M.A. Pastor-Corrales (eds.). Bean production problems in the tropics (2nd ed.). Centro Interna- cional de Agricultural Tropical, Cali, Colombia. Steel, R.G.D. and J.H. Torrie. 1960. Principles and procedures of statistics. McGraw-Hill, New York.

Walker, J.C. 1946. Soil management and plant nutrition in relation to disease development. Soil Sci. 61:47-54

Zaiter, H.Z., D.P. Coyne, R.B. Clark, and D.S. Nuland. 1986. Field nutrient solution and temperature effect upon iron leaf chlorosis of dry beans (Phaseolus vulgaris L.). J. Plant Nutr. 9:397-415. 